\title{
THE TREATMENT OF NEUROSYPHILIS BY INDUCTOPYREXIA AND CHEMOTHERAPY
}

\author{
By R. C. L. BATCHELOR, M.A., M.B., D.P.H., F.R.C.S.Ed. \\ Clinical Medical Officer, Venereal Diseases Scheme, Edinburgh Corporation
}

G. M. THOMSON, M.D., D.P.H.

Temporary Assistant, Venereal Diseases Department, Royal Infirmary, Edinburgh

and J. L. HUGGAN, M.B., Ch.B.

This report deals with the treatment of and the subsequent observations made upon twenty-two patients with various types of neurosyphilis. Although the number of cases is small the results obtained are encouraging and they are published now so as to be available for association and comparison with those of other centres.

\section{Fever therapy}

The production of artificial fever has been by means of the Inductotherm Fever Cabinet which combines the principles of elevation of the temperature by short wave high frequency current and maintenance of the temperature by highly saturated air at a temperature not exceeding $110^{\circ} \mathrm{F}$. It is possible to raise the patient's temperature to $106^{\circ} \mathrm{F}$. in two to two-and-a-half hours and to keep it at any desired level thereafter. The details of the technique have already been published (Thomson, 1941).

It is reported that the best results in the treatment of neurosyphilis are obtained by the use of twelve sessions of fever, each of three hours at $105.8^{\circ} \mathrm{F}$. Instead of attempting to apply such a uniform treatment, we have'found it more practicable to plan a separate schedule of treatment for each individual patient, having regard to such factors as his age, physical condition, stage of disease and occupation. The standard aimed at has been to attain as nearly as possible thirty hours at (or over) a temperature level of $105^{\circ} \mathrm{F}$., given in from eight to twelve treatments. Certain patients, for various reasons, received smaller amounts of fever at lower temperatures for as little as seven-and-a-half hours and in six cases it was thought advisable on clinical grounds to give a longer course of pyrexia. All patients were in hospital for the first four to six treatments and were allowed to attend thereafter as out-patients if their mental state was satisfactory. Fever sessions were given, in the absence of complications, twice weekly to in-patients and once weekly to out-patients. If attending as out-patients they spent the night after treatment in the ward or were sent home by taxi.

\section{Chemotherapy}

It is generally conceded that it is advisable to employ chemotherapy in conjunction with fever therapy. so tryparsamide and bismuth were given to the first eight patients during the course of their-fever, but on a different day from the pyrexial session. Seven of those patients later developed toxic hepatitis and subsequently the tryparsamide was omitted. Now bismuth only is used, 0.2 gramme twice per week during the course of treatment...Immediately after treatment tryparsamide and bismuth are given in maximum doses for from six to eighteen months. In those cases in which there is known to be optic nerve involvement, tryparsamide is not given, but " 914 "' is substituted or bismuth is used alone.

During their stay in hospital, most of the patients have had supplementary injections of vitamin $B_{1}, 30$ milligrams twice weekly, and, when practicable, general ultra-violet light irradiation has also been given.

One of the most striking cases (No. 22) is that of a professional man who was in a mental home incapacitated through loss of memory, dysarthria and general 
THE BRITISH JOURNAL OF VENEREAL DISEASES

\begin{tabular}{|c|c|c|c|c|c|c|c|c|c|c|c|c|c|c|}
\hline \multirow{3}{*}{ 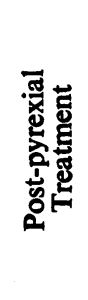 } & $\dot{m}$ & $=$ & $\simeq$ & $\tilde{\sigma}$ & $\infty$ & \pm & $\simeq$ & 으 & $m$ & $n$. & $r$ & $\equiv$ & & 으 \\
\hline & $\dot{\dot{a}}$ & 6 & $\simeq$ & I & $\Xi$ & 1 & $\nabla$ & 1 & 1 & 1 & 1 & 1 & జ్త & $N$ \\
\hline & 岕 & ๙̊ & 으 & 1 & $\bar{\sim}$ & ถิ & 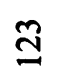 & $\overline{0}$ & $\tilde{6}$ & Y & $\check{n}$ & 1 & & $\tilde{n}$ \\
\hline \multicolumn{2}{|c|}{ วุฒ1S } & 3 & $\infty$ & 3 & 3 & 3 & 3 & 3 & 3 & 3 & 3 & 3 & & 3 \\
\hline \multirow{3}{*}{ 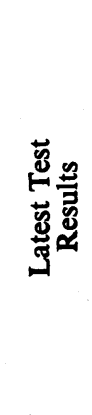 } & 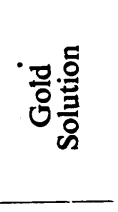 & $\begin{array}{l}8 \\
\frac{8}{8} \\
\frac{8}{8}\end{array}$ & $\begin{array}{l}8 \\
8 \\
8 \\
8 \\
8\end{array}$ & 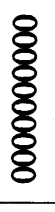 & 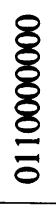 & $\begin{array}{l}8 \\
8 \\
8 \\
8 \\
8 \\
8\end{array}$ & $\begin{array}{l}8 \\
8 \\
8 \\
8 \\
8\end{array}$ & $\begin{array}{l}8 \\
\frac{8}{\bar{N}} \\
\frac{\pi}{\sim}\end{array}$ & $\begin{array}{l}8 \\
8 \\
8 \\
8 \\
8\end{array}$ & $\frac{\delta}{\delta} \frac{8}{\tilde{~}}$ & $\begin{array}{l}8 \\
8 \\
8 \\
8 \\
8\end{array}$ & $\begin{array}{l}8 \\
8 \\
8 \\
8 \\
\end{array}$ & 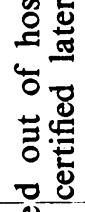 & $\begin{array}{l}8 \\
\text { \&్ } \\
8 \\
8 \\
8\end{array}$ \\
\hline & 嵌资 & | & $i$ & 1 & $H$ & $H$, & 1 & $H$ & $H$ & + & 1 & 1 & 疍 & | \\
\hline & 客孚 & 1 & & + & 1 & + & 1 & 1 & 1 & 1 & | & 1 & ర్d & 1 \\
\hline \multicolumn{2}{|c|}{ 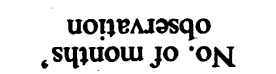 } & mे & 유 & ర్ల & ลे & $\stackrel{\sim}{N}$ & $\stackrel{\sim}{\sim}$ & $\tilde{\sim}$ & ก & $\bar{\sim}$ & 9 & $\infty$ & 总 & 6 \\
\hline \multicolumn{2}{|c|}{ 'H SOI ie SInoH } & $+n$ & 요 & 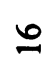 & $m$ & $\tilde{\sim}$ & $\mathcal{F}$ & 유 & $\hat{m}$ & Дิ & 유 & $\grave{N}$ & $\because$ & $\approx$ \\
\hline \multicolumn{2}{|c|}{ suo!ssas IOAәH Jo 'ON } & $\simeq$ & 으 & $a$ & $\simeq$ & $\infty$ & $\simeq$ & $\infty$ & $\simeq$ & 으 & $a$ & $\infty$ & $\infty$ & 으 \\
\hline \multirow{3}{*}{ 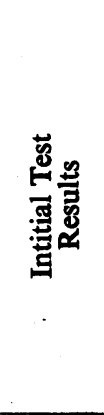 } & 홍윻 & $\frac{8}{\frac{8}{8}}$ & 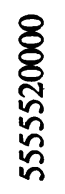 & 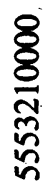 & $\frac{8}{\delta}$ & 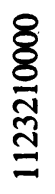 & $\begin{array}{l}8 \\
\delta \\
\frac{8}{\sim} \\
\text { స్ }\end{array}$ & $\frac{8}{8}$ & \begin{tabular}{l}
8 \\
\multirow{2}{*}{} \\
$n$ \\
$n$ \\
$n$ \\
$n$
\end{tabular} & 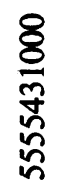 & 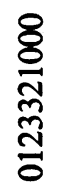 & $\begin{array}{l}8 \\
8 \\
8 \\
8 \\
\end{array}$ & $\begin{array}{l}8 \\
\frac{8}{n} \\
n \\
n \\
n \\
n\end{array}$ & $\frac{8}{\frac{8}{8}}$ \\
\hline & 岁告 & + & $\begin{array}{l}+ \\
+ \\
+\end{array}$ & $\begin{array}{l}+ \\
+ \\
+\end{array}$ & $\begin{array}{l}+ \\
+ \\
+\end{array}$ & $\begin{array}{l}+ \\
+ \\
+\end{array}$ & + & $\begin{array}{l}+ \\
+ \\
+\end{array}$ & $\begin{array}{l}+ \\
+ \\
+\end{array}$ & $\begin{array}{l}+ \\
+ \\
+\end{array}$ & $\begin{array}{l}+ \\
+ \\
+\end{array}$ & $\begin{array}{l}+ \\
+\end{array}$ & $\begin{array}{l}+ \\
+ \\
+\end{array}$ & + \\
\hline & 它 & 1 & $\begin{array}{l}+ \\
+ \\
+\end{array}$ & $\begin{array}{l}+ \\
+ \\
+\end{array}$ & $\begin{array}{l}+ \\
+ \\
+\end{array}$ & $\begin{array}{l}+ \\
+ \\
+\end{array}$ & $\begin{array}{l}+ \\
+ \\
+\end{array}$ & $\begin{array}{l}+ \\
+ \\
+\end{array}$ & 1 & $H$ & $\begin{array}{l}+ \\
+ \\
+\end{array}$ & $\begin{array}{l}+ \\
+ \\
+\end{array}$ & $\begin{array}{l}+ \\
+ \\
+\end{array}$ & 1 \\
\hline \multicolumn{2}{|c|}{ PIEIS } & ロ & $\varpi$ & 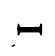 & 3 & $\mapsto$ & $\mapsto$ & 3 & $\varpi$ & $B$ & $\varpi$ & 3 & $\varpi$ & 3 \\
\hline \multicolumn{2}{|c|}{ 、 旁总 } & نْ & نَّهَ & نب & $\stackrel{\leftrightarrow}{H}$ & نَّ & بْ & $\underset{0}{\stackrel{\alpha}{\alpha}}$ & $\underset{ن}{\stackrel{\alpha}{\alpha}}$ & 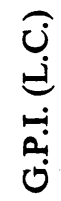 & نَّ & $\begin{array}{c}\widehat{u} \\
\dot{j} \\
\dot{z} \\
z\end{array}$ & نَّن & 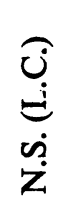 \\
\hline \multicolumn{2}{|c|}{ Iəqumn $\mathbf{N}$ əsep } & - & $N$ & $m$ & $\theta$ & $n$ & 6 & $N$ & $\infty$ & $a$ & 으 & $=$ & & 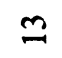 \\
\hline
\end{tabular}


THE TREATMENT OF NEUROSYPHILIS

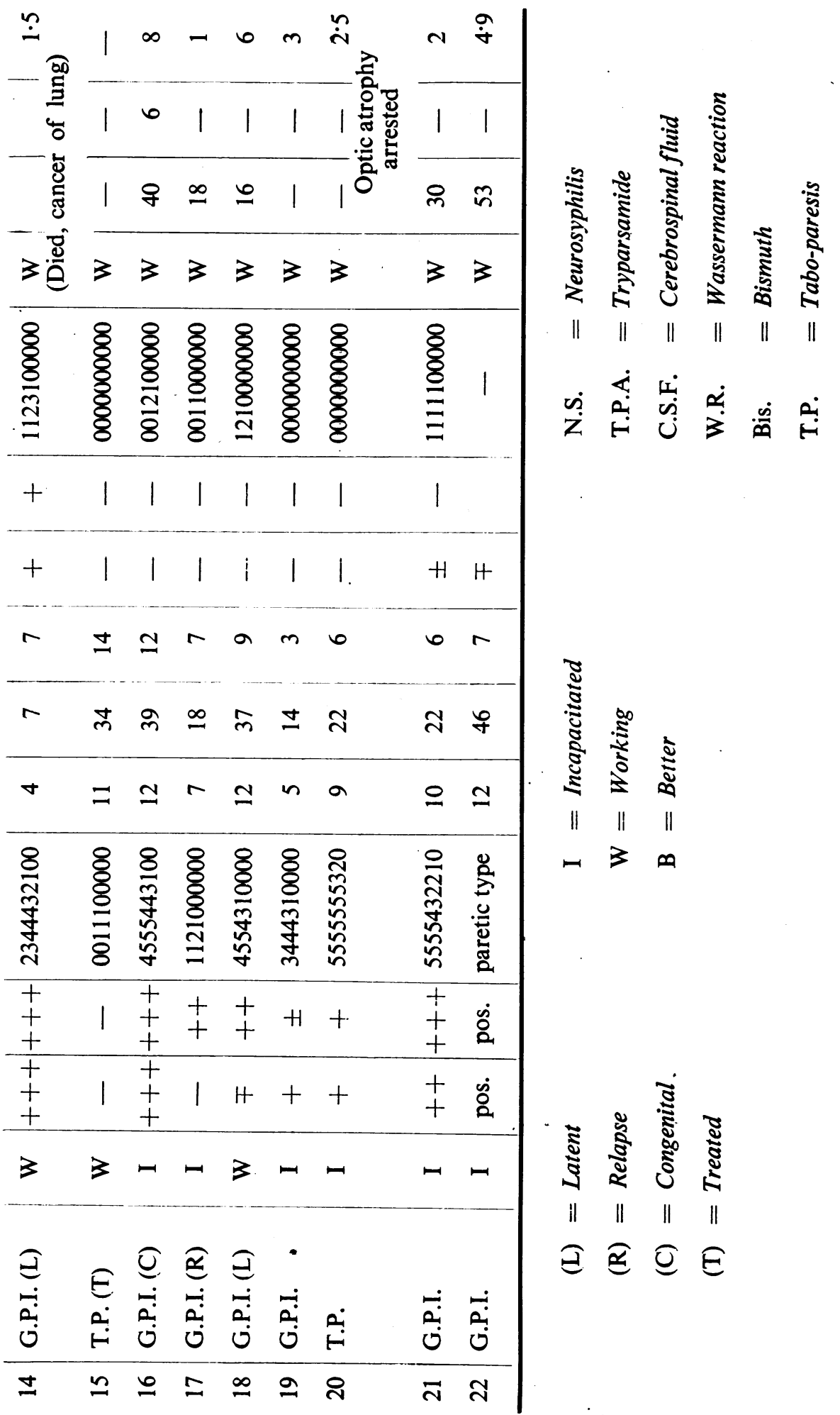




\title{
THE BRIWISH JOURNAL OF VENEREAL DISEASES
}

mental enfeeblement, and who: is now doing a full day's work and taking his full share of responsibility.

\section{Conclusion}

A definite conclusion cannot be drawn from such a small group of cases with comparatively short periods of observation, but the evidence so far accumulated indicates that further trial of the methods described is amply justified.

REFERENCES

Thomson, G. M. (1941) Edinb. med. J., 48, 629.

\section{JAUNDICE IN SYPHILITICS*}

\author{
By MAJOR J. MARSHALL, R.A.M.C. \\ Command Venereologist, Eastern Command and London District
}

The following survey summarizes my general observations on an investigation of cases of jaundice occurring in syphilitics, treated and untreated, in the past two years, and reviews the main points in our present knowledge of the subject.

\section{War-time increase in jaundice}

I first noticed a local increase in the incidence of jaundice occurring in my syphilitic patients about two years ago, and in April, 1941 the numbers were high enough for me to circularize my colleagues in other Commands to see whether they had noticed a similar increase. None of them, at that time, was aware of any notable rise in incidence, but two people reported a slight increase. From small beginnings the increase has continued until it now constitutes a major problem.

I have felt from the first that jaundice during arsenical treatment was not a distinct clinical entity, and have always tried to compare my cases with those of infective hepatitis patients who were not syphilitic. It now seems to me that the jaundice coincident with arsenical treatment is only a small, but not insignificant, part of what is really a pandemic of jaundice, occurring in many different types of individuals and having different predisposing factors, but due essentially to a disturbance of liver function leading through various pathological states of the liver cells either to necrosis of these cells or to their recovery. All my observations have supported this view and $I$ have seen in the last two years about 600 patients with jaundice, half in cases of treated syphilis and half in otherwise healthy individuals.

During the whole of the present war period the antisyphilis treatment used in the area from which most of my cases came has been the same. Early syphilis is treated with a minimum of four courses of neoarsphenamine and bismuth. Courses are of ten weekly injections of 0.6 gramme of neoarsphenamine and 0.2 gramme of bismuth with a month's rest between the courses. The therapeutic results in syphilis have been very good with this dosage.

We know: that the incidence of syphilis has increased, and that treatment complications must obviously also increase. Although the incidence of dermatitis and other complications which are directly due to arsenic have appeared subsequent upon the increase in syphilis, the incidence of jaundice has gone far above the highest previously quoted average. As jaundice and hepatitis can occur for a variety of reasons in the course of syphilis and its treatment, I think it wise to consider all the types that may be encountered, for they are important in differential diagnosis.

The varieties of jaundice in untreated syphilis

Hepatitis with or without jaundice can occur at any stage of acquired or congenital syphilis.

* An address to the Medical Society for the Study of Venereal Diseases, March, 1943. 